Jurnal Pengajian Melayu - JOMAS, Jilid 32(2), 2021: 74-93

\title{
CABARAN HIDUP PENGHIDAP HIV DALAM KALANGAN WANITA
}

\author{
(LIFE CHALLENGE OF HIV-POSITIVE AMONG WOMEN)
}

\author{
Mashrom Muda \\ mashrom@um.edu.my \\ Akademi Pengajian Melayu \\ Universiti Malaya, Kuala Lumpur \\ Malaysia
}

Received: 7th February 2021; Accepted: 4th October 2021; Published: 26th October 2021

\begin{abstract}
The spread of the human immunodeficiency virus (HIV) has been detected for almost 40 years, beginning in the 1980s and still remains a global health issue. HIV-positive infections can now be detected in almost all countries, including Malaysia. The cross-border, complex, dynamic and unpredictable nature of HIV makes the epidemic a global issue and not simply a domestic issue of any particular country. The changing trends of infection are also causing fear to many as more cases are being detected among individuals not involved in risky activities, such as drug abuse and prostitution among women and teenagers. Consequently, the challenges faced by persons with HIV are different for every segment. Specifically, HIV-positive women (PHW) have also been found to face more severe consequences than their male counterparts due to factors such as inequality of power and opportunities and gender differences. This study is conducted to examine the challenges and their effects to understanding what PHWs face. A qualitative study conducted on 20 PHWs found various challenges faced by these women, such as unstable health; being stigmatised and discriminated against; and negatively labelled by family members and members of society in various situations. The challenges faced by the PHWs indirectly affect many aspects of their lives, such as receiving insufficient social support; denied rights and opportunities to seek treatment and employment; barred from community activities; inability to make decisions; and always being in a state of grief, frustration and stress. Therefore, support is desperately needed by the PHW to rebuild their lives.
\end{abstract}

Keywords: HIV-positive, women sufferers, challenges, stigma, discrimination. 


\begin{abstract}
Abstrak
Penularan wabak Human Immunodeficiency Virus atau HIV positif telah dikesan sejak hampir 40 tahun (bermula tahun 1980-an) yang lalu, namun statusnya kini masih lagi kekal sebagai isu kesihatan global. Kini, jangkitan HIV positif dapat dikesan hampir keseluruhan negara di dunia, termasuk Malaysia. Sifat HIV positif yang merentasi sempadan, kompleks, dinamik dan sukar diramal jangkitannya itu telah menjadikan wabak HIV positif ini isu sejagat dan bukan isu dalaman sesebuah negara sahaja. Corak jangkitan yang sentiasa berubah-ubah mendatangkan kegerunan kepada banyak pihak kerana kini kes HIV positif lebih banyak dikesan dalam kalangan individu yang tidak terlibat dengan kegiatan berisiko seperti menagih dadah atau kes pelacuran yang melibatkan wanita dan gadis remaja. Menjalani kehidupan sebagai seorang penghidap HIV positif adalah berbeza bagi setiap kumpulan. Bagi penghidap HIV positif wanita (PHW), mereka sebenarnya menerima kesan yang lebih teruk berbanding penghidap lelaki disebabkan faktor seperti ketaksamaan kuasa, perbezaan jantina dan peluang yang tidak sama rata. Bagi memahami cabaran yang dihadapi oleh PHW, satu penelitian telah dilakukan untuk mengetahui bentuk-bentuk cabaran dan kesannya kepada kehidupan masyarakat. Kajian kualitatif yang melibatkan seramai 20 orang PHW mendapati bahawa, mereka berhadapan dengan pelbagai cabaran seperti tahap kesihatan yang tidak menentu, distigma, didiskriminasikan dan diberikan label negatif oleh ahli keluarga sendiri dan anggota masyarakat dalam pelbagai situasi. Cabaran yang dihadapi oleh PHW secara tidak langsung menjejaskan banyak aspek dalam kehidupan mereka seperti tidak mendapat sokongan sosial, dinafikan hak dan peluang untuk mendapatkan rawatan, pekerjaan, aktiviti bermasyarakat, tidak bebas membuat keputusan serta sentiasa dalam keadaan bersedih, kecewa dan tekanan. Sehubungan dengan itu, sokongan sangat diperlukan oleh PHW untuk membina kembali kehidupan mereka.
\end{abstract}

Kata Kunci: HIV positif, penghidap wanita, cabaran, stigma, diskriminasi.

\title{
Pengenalan
}

Kemunculan wabak Human Immunodeficiency Virus (HIV) positif sejak lebih 40 tahun lalu (sekitar tahun 1980-an) terus kekal menjadi isu kesihatan global dan menjadi ketakutan sehingga hari ini. Wabak HIV positif dan sindrom kurang ketahanan melawan penyakit atau Acquired Immune Deficiency Syndrome (AIDS) yang belum ditemui penawarnya sehingga kini dapat dikesan hampir di seluruh dunia sama ada negara miskin mahupun negara maju. Perkara yang menjadi kebimbangan banyak pihak sejak akhir-akhir ini ialah peningkatan pola penularan yang melibatkan penghidap HIV positif dalam kalangan kaum wanita (PHW). Pada awal kemunculannya, HIV positif lebih banyak dikesan dalam kalangan penghidap lelaki, kini coraknya telah berubah kepada wanita serta menjadi penyumbang utama kes HIV positif di seluruh dunia. Badan kesihatan dunia seperti World Health Organization (WHO) turut mengesahkan separuh daripada jumlah penghidap HIV positif di seluruh dunia pada hari ini terdiri daripada kaum wanita dan menjadi punca utama kematian (UNAIDS, 2021; WHO, 2021). 
Berdasarkan catatan kes, sehingga tahun 2019, terdapat seramai 38.0 juta orang (36.2 juta orang penghidap dewasa) telah dijangkiti HIV positif di seluruh dunia. Penghidap HIV positif dalam kalangan kaum wanita menyumbang seramai 19.2 juta orang berbanding penghidap HIV positif dalam kalangan kaum lelaki, iaitu seramai 17.0 juta orang dan trend ini semakin meningkat setiap tahun (WHO, 2021). Perubahan drastik ini dikatakan berpunca daripada sifat HIV positif itu sendiri yang semakin dinamik, kompleks, unik dan sukar diramal (Infante, et al., 2009). Selain itu, pelbagai aspek lain turut dikenal pasti seperti ketaksamaan kuasa, perbezaan jantina, kedudukan yang subordinat, kemiskinan dan sebagainya (Puri et al., 2010). Kebimbangan banyak pihak terhadap peningkatan kes yang melibatkan PHW sebenarnya berasas kerana banyak kes yang dikesan hari ini melibatkan wanita muda dan gadis remaja. Jika sebelum ini kes banyak dikesan dalam kalangan mereka yang terlibat dengan kegiatan tidak bermoral seperti penagihan dadah atau pelacuran (menjadi pelacur), tetapi kini telah berubah, iaitu tidak terlibat dengan perkara-perkara berisiko. Jumlah jangkitan yang paling tinggi direkodkan ialah dijangkiti melalui suami/pasangan yang telah dijangkiti dengan virus HIV positif dan AIDS serta terlibat dengan kegiatan berisiko tanpa pengetahuan mereka (Shrestha et al., 2016).

Selain berisiko tinggi dijangkiti dan menjangkiti, PHW sebenarnya lebih terkesan berbanding dengan penghidap lelaki apabila mereka bergelar penghidap HIV positif (Quinn \& Overbaugh, 2005). Antara yang boleh dilihat ialah jumlah kes semakin meningkat, masalah kesihatan, banyak lagi aspek lain dalam hidup mereka terjejas termasuk aspek sosial, ekonomi, emosi dan psikologi (Siegel \& Lekas, 2002). Stigma, diskriminasi dan pelbagai label serta konotasi negatif daripada anggota masyarakat menambahkan lagi masalah dalam kalangan PHW. Menjalani kehidupan sebagai seorang penghidap HIV positif bukan suatu perkara yang mudah bagi mereka kerana berhadapan dengan pelbagai kesan, cabaran dan dugaan. Malah, ada dalam kalangan PHW yang tidak dapat menerima kenyataan dijangkiti HIV positif dan hanya memikirkan perkara-perkara negatif bertahun lamanya seperti 'menunggu mati', penyakit 'malu', 'jijik' 'kotor' dan 'orang benci'. Malahan ada juga PHW yang berhasrat menamatkan riwayat hidup mereka sendiri kerana terlalu kecewa, sedih dan marah (Mashrom Muda, 2018). Keadaan PHW menjadi semakin tertekan apabila mereka memikirkan peluang lain dalam hidup seperti dalam bidang pekerjaan, pendidikan, membuat keputusan, perkahwinan, mengandung dan melahirkan anak kini sudah berkurang atau sudah tiada. Memikirkan perkara-perkara negatif dianggap sebagai tindakan spontan dalam kalangan PHW kerana nilai positif dalam diri mereka semakin menurun, meningkatkan pemisahan, pengasingan dan pengecualian sosial sehingga berlaku kehilangan status (Mukolo et al., 2013).

Cabaran bergelar penghidap HIV positif sebenarnya bersangkutan juga dengan tindakan sesetengah anggota masyarakat yang secara berpanjangan memberi tekanan kepada golongan penghidap HIV positif seperti PHW. Malah, menurut Fee dan Parry (2008), seseorang penghidap HIV positif berhadapan dengan tiga cabaran utama apabila mereka dijangkiti, iaitu (1) kesan jangkitan HIV; (2) kesan AIDS; dan (3) kesan sosial, budaya, ekonomi dan politik. Kesan yang paling ditakuti ialah kesan ketiga kerana adanya elemen stigma, diskriminasi dan pelbagai bentuk penafian (Shamos et al., 2009) sehingga menjejaskan kehidupan penghidap dan proses untuk mengawal wabak ini juga bermasalah. Akibat stigma, diskriminasi dan label ini juga menyebabkan ada dalam kalangan PHW yang beranggapan bahawa kesejahteraan hidup mereka telah berakhir, tiada lagi kebahagiaan dan segalanya telah musnah. 
Pemikiran serta pandangan negatif terhadap diri sendiri juga sebenarnya sangat bahaya kepada PHW kerana boleh mempengaruhi mereka untuk melakukan perkara di luar jangka atau melakukan perkara seperti dilabel, antaranya menagih dadah, menjadi melacur dan berniat untuk menamatkan riwayat hidup sendiri (Mashrom Muda, 2019). Penggunaan dadah dan alkohol misalnya dikatakan untuk mengurangkan tekanan dihadapi disebabkan ada dalam kalangan PHW yang tidak dapat menerima kenyataan bergelar penghidap HIV positif. Malah, kajian yang dilakukan oleh Vosvick, et al. (2002; Unger \& Collins, 2005) turut membuktikan bahawa, penghidap HIV positif berisiko tinggi untuk terlibat dengan penyalahgunaan dadah dan alkohol sebagai cara untuk mengatasi tekanan yang dihadapi oleh mereka.

Tingkah laku atau niat untuk menamatkan riwayat hidup pula sebenarnya lebih cenderung dalam kalangan PHW kerana mereka berhadapan dengan pelbagai cabaran seperti faktor umur, sokongan sosial yang lemah, tahap pendidikan, jenis keluarga, hubungan tidak stabil dan menjadi mangsa penderaan fizikal, seksual dan emosi (Adeyemo et al., 2019). Situasi ini sekiranya tidak dikawal dengan sebaiknya boleh mendatangkan kesan lebih teruk terutamanya dalam konteks kesihatan awam.

Bagi PHW yang tidak berupaya berhadapan dengan stigma, diskriminasi dan label negatif daripada anggota masyarakat, rakan dan ahli keluarga sendiri, mereka cenderung untuk berada dalam kesedihan, kemurungan, kecewa, ketakutan, kebimbangan, tertekan dan mengasingkan diri daripada orang ramai. Sebenarnya perasaan bercampur baur dalam diri PHW berkait juga dengan sikap suami/pasangan mereka yang menyebarkan virus maut ini. Suami/pasangan yang selama ini dianggap sebagai pelindung, sebenarnya menjadi pemusnah kehidupan mereka kerana terlibat dengan kegiatan tidak bermoral (Shrestha et al., 2016).

Akibatnya, penghidap wanita gagal untuk membina kembali kehidupan mereka, malah tahap kesejahteraan juga merosot seperti kesihatan, pendidikan serta pekerjaan (Nik Shahrizan Nik Mad, et al., 2020). Tekanan anggota masyarakat termasuklah mitos yang sukar dibendung sehingga hari ini, iaitu berpandangan bahawa semua penghidap HIV positif adalah sama lelaki mahupun wanita. Sebenarnya, tanggapan masyarakat terhadap PHW terlibat dengan kegiatan berisiko ini berlaku di seluruh dunia dan bukan di Malaysia sahaja. Menurut Nachega et al. (2012), ada lima tanggapan utama yang selalu dilemparkan kepada penghidap seperti PHW, iaitu (1) terlibat dengan tingkah laku berisiko seperti pergaulan seksual, penggunaan dadah dan pelacuran, (2) hidup tidak lama, (3) perlu disingkirkan, (4) mudah berjangkit kepada pihak lain melalui aktiviti harian, dan (5) mempunyai bentuk fizikal yang berbeza. Tanggapan ini juga dialami oleh kebanyakan PHW sehingga menjadi cabaran terbesar mereka untuk menjalani kehidupan sosial seperti individu normal atau sihat lain walaupun sokongan sosial sangat berkesan. Telah terbukti juga bahawa, PHW yang diterima baik oleh ahli keluarga dan anggota masyarakat menjadi lebih kuat dan berupaya membina kembali kehidupan dan melawan segala bentuk stigma, diskriminasi serta label negatif yang diberikan (Mashrom Muda \& Rahimah Abdul Aziz, 2018).

Namun begitu, dari setahun ke setahun masalah sama masih lagi berlaku, jumlah kes juga semakin lama semakin meningkat. Apabila bergelar penghidap HIV positif, PHW secara tidak 
langsung berhadapan dengan cabaran stigma, diskriminasi dan dilabel. Tidak cukup dengan situasi itu, PHW turut dipulau, disingkirkan, dikeji dan diperlakukan dengan pelbagai perlakuan negatif lain sehingga meletakkan PHW dalam situasi yang amat menyedihkan. Tindak balas oleh pihak yang tidak boleh menerima kehadiran PHW dalam persekitaran mereka dikatakan berlaku secara automatik dan hadir bersama dengan status HIV positif itu sendiri serta paling ditakuti oleh penghidap seperti PHW (Herek, 2002). Hal ini kerana, stigma, diskriminasi dan label negatif dianggap sebagai hukuman paling berat kepada mereka dan mampu memberi kesan ke atas semua aspek kehidupan mereka. Oleh itu, artikel ini adalah berkaitan dengan cabaran selepas bergelar penghidap HIV positif dalam kalangan wanita terutamanya dalam konteks stigma, diskriminasi dan label negatif serta pengaruh ke atas kehidupan mereka.

\section{Sorotan Kajian}

Sesuai dengan statusnya sebagai isu kesihatan global, sehingga kini telah banyak kajian dilakukan berkaitan penularan wabak HIV positif ini, terutamanya isu transmisi, faktor jangkitan, golongan berisiko, kesan, stigma, diskriminasi, langkah pencegahan dan pelbagai lagi. Kajian turut dilakukan di luar negara dan di dalam negara yang menjadi sumber maklumat penting berkaitan isu kesihatan global ini. Di Malaysia juga banyak kajian dilakukan walaupun kes melibatkan penghidap wanita seperti PHW sebenarnya dianggap masih baru. Kajian dilakukan oleh Aishah @ Eshah (2006) mendapati bahawa, golongan wanita mudah terdedah dan dijangkiti oleh virus HIV positif dan AIDS melalui hubungan seksual, parenteral atau perinatal berbanding golongan lelaki. Apabila dijangkiti, mereka mula dikawal segala hak, sumber, dan peluang berasaskan pelbagai faktor, terutamanya perbezaan jantina. Selepas bergelar PHW secara automatik juga mereka dibeza-bezakan dengan orang lain, terutamanya dengan penghidap lelaki seperti tidak diberikan peluang untuk bercakap atau berkomunikasi mengenai isu kesihatan. Akibatnya, PHW tidak mendapat peluang yang sama rata seperti kawalan sumber material, informasi serta kawalan ke atas diri mereka sendiri.

Kajian seterusnya turut mendedahkan bahawa, PHW dinafikan segala hak serta peluang sama ada sebagai seorang individu ataupun anggota masyarakat (Aishah @ Eshah, 2009). Hak sebagai individu paling mencabar dan teruk diterima oleh PHW seperti hak mendapatkan hubungan seks selamat menggunakan kondom. Bercakap mengenai hubungan seksual dan mengatakan 'tidak' kepada permintaan suami/pasangan (termasuk meminta pasangan menggunakan kondom) juga dihalang kerana boleh dituduh sebagai penderhaka. Malah, meletakkan PHW dalam risiko seperti menjadi mangsa penderaan sama ada secara fizikal, emosi mahupun seksual.

Kajian HIV positif ke atas golongan wanita muda dan gadis remaja menurut Badariah et al. (2015) dapat dilihat dalam konteks sumber informasi atau maklumat mengenai penularan wabak maut ini. Golongan wanita dan gadis remaja berisiko kerana mereka sebenarnya tidak mendapat maklumat betul dan tepat sehingga menjadikan jumlah kes dalam kalangan mereka meningkat dari semasa ke semasa. Sebagai contoh, kajian dilakukan ke atas lebih daripada 800 orang responden mendapati bahawa, sebahagian besar daripada mereka yang berumur antara 13 hingga 30 tahun berpandangan HIV positif hanya berjangkit melalui transmisi darah, manakala 
dua pertiga yang lain mengaitkan penularan wabak maut ini dengan bendalir badan lain. Ada juga dalam kalangan responden berumur antara 12 hingga 15 tahun percaya badan yang sihat tidak akan dijangkiti oleh virus HIV positif. Dapatan ini membuktikan bahawa, risiko kepada golongan wanita muda dan gadis remaja sangat tinggi. Malah trend pengetahuan ini boleh memberi impak yang besar kepada kualiti kehidupan golongan muda masa hadapan.

Kajian oleh Mashrom Muda (2018), mengenai kualiti kehidupan dan pemerkasaan diri penghidap HIV positif wanita pula mendapati bahawa, banyak aspek dalam kehidupan mereka telah terjejas setelah dijangkiti HIV positif. Mereka bukan sahaja tidak diterima dalam masyarakat, malah mereka kehilangan banyak peluang yang sepatutnya mereka perolehi. Kajian dilakukan juga mendapati, pada peringkat awalnya mereka tidak dapat menerima kenyataan dijangkiti virus HIV positif. Tambahan lagi dijangkiti pada usia yang sudah lanjut, dalam keadaan tidak terlibat dengan apa-apa perlakuan berisiko dan hanya menjadi suri rumah tangga. Setelah mereka berjumpa dengan kakitangan kesihatan seperti nurse, doktor, kaunselor serta mendapatkan rawatan kesihatan, akhirnya mereka boleh menerima ketentuan Ilahi. Malah, beranggapan bahawa kes jangkitan HIV positif sebagai 'Teguran Allah'. Ada dalam kalangan penghidap wanita akhirnya mampu bangkit kembali dengan adanya sokongan sosial dan bantuan daripada ramai pihak sama ada secara top-down, ataupun bottom-up. Malah, kajian turut mendapati bahawa penghidap wanita sebenarnya boleh membina dan membangunkan kembali kehidupan sosial mereka seperti individu sihat yang lain apabila diberikan peluang sama rata.

Cabaran seperti peluang dan hak yang terhad dalam kalangan PHW juga sebenarnya telah lama dikaji. Golongan wanita selain berisiko tinggi dijangkiti, mereka sebenarnya gagal atau sukar untuk mempertahan diri mereka daripada terus menjadi mangsa. Menurut Office of Women's Health (2021), jangkitan HIV positif itu sendiri menjadi isu kesihatan yang paling utama bagi PHW, namun peluang yang terhad menyebabkan mereka gagal untuk bercakap isu kesihatan seperti hubungan seksual selamat dengan menggunakan kondom seperti diperkatakan oleh Aishah @ Eshah (2009). Cabaran ini juga menyebabkan PHW sentiasa berisiko untuk mendapat penyakit sampingan lain terutamanya tularan seks (Sexually Transmitted Diseases atau STD) atau jangkitan kelamin seperti sifilis dan gonorea.

Dijangkiti HIV positif juga menyebabkan berlakunya penurunan status kesihatan dalam kalangan PHW. Menurut Singh \& Dixit (2010), aspek kesihatan menjadi domain penting untuk mengukur tahap kualiti kehidupan individu dan masyarakat. Kehidupan dianggap tidak lengkap dan sempurna seandainya tahap kesihatan merosot seperti dihadapi oleh PHW. Penghidap wanita apabila disahkan dijangkiti virus HIV positif, ramai dalam kalangan mereka yang terkejut dan tidak dapat menerima kenyataan sehingga ada yang jatuh sakit. Cabaran kesihatan yang biasa dilaporkan ialah seperti hilang selera makan, penyusutan berat badan, masa tidur terganggu, tidak mendapat waktu rehat yang cukup, demam dan batuk berpanjangan serta mudah diserang penyakit lain. Malah, isu kesihatan selepas dijangkiti HIV positif menjadi isu besar, penting dan paling ditakuti oleh PHW sendiri dan pihak lain kerana kesannya kepada aspek sosial, ekonomi, politik, emosi serta psikologi (holistik).

Di samping itu, pengkaji seperti Mbonu et al. (2010) pula melihat cabaran kesihatan dengan aspek ketaksamaan dalam kalangan penghidap wanita seperti layanan diterima atau 
diberikan adalah berbeza. Dalam masyarakat hari ini, isu berkaitan kuasa (autority) bukan suatu perkara baru, malah diterima secara kolektif oleh anggota masyarakat. Dalam konteks kesihatan, penghidap lelaki diberi kuasa dominan, manakala penghidap wanita sering dipinggirkan. Malah penghidap lelaki yang mempunyai kuasa mampu menyembunyikan status HIV positif dalam diri mereka daripada pengetahuan masyarakat dan pasangan berbanding dengan penghidap wanita. Antara alasan diberikan dalam konteks ketaksamaan kuasa ini ialah (1) lelaki mengambil / membuat segala keputusan dalam keluarga dan sebahagian besarnya tidak memerlukan pertolongan dan sokongan isteri untuk mendapatkan rawatan, (2) wanita tidak boleh mempersoalkan keputusan lelaki sekiranya mereka tidak mahu mendedahkan status kesihatan. Situasi dialami PHW juga ada kaitan dengan kedudukan wanita yang subordinat dan inferior sehingga menafikan segala hak mereka (Puri et al., 2010).

Penghidap wanita yang dijangkiti HIV positif tidak boleh menyembunyikan status kesihatan mereka berbanding lelaki kerana isu-isu seperti reproduktif atau antenatal. Tambahan lagi penghidap wanita lebih memerlukan sokongan suami/pasangan apabila mereka berhadapan dengan cabaran kesihatan. Status kesihatan yang terbongkar implikasinya sangat besar terutamanya untuk mendapatkan rawatan (awalan, susulan dan rawatan masa hadapan). Mbonu turut memetik luahan informan dalam kajiannya seperti berikut, "...imagine how my husband hide his HIV status from me, so I now have HIV/AIDS from him. If I was a man, I would not be in this condition because would know my self..." (Mbonu, et al., 2010:3).

Kajian serupa turut dilakukan oleh Loutfy et al. (2015) ke atas penghidap HIV positif wanita dan mendapati bahawa isu dan cabaran kesihatan dialami dalam kalangan penghidap wanita tidak dapat dipisahkan. Sebelum atau selepas dijangkiti HIV positif, wanita tidak boleh lari daripada isu kesihatan kerana kehidupan mereka dilingkari dengan pelbagai rangkaian tanggungjawab. Wanita yang menghidapi HIV positif bukan sahaja bertanggungjawab sebagai seorang ibu dan isteri, malah turut berperanan sebagai anak, pekerja ( 24 jam sehari, bergaji atau tidak bergaji), penjaga, jururawat untuk ahli keluarga dan pelbagai tanggungjawab yang tidak mampu dilakukan oleh pihak lain.

Selain isu kesihatan, penghidap wanita yang dijangkiti HIV positif turut mempunyai masalah dalam konteks perhubungan atau komunikasi sama ada dalam lingkungan keluarga mahupun luar lingkungan keluarga. Komunikasi berkesan antara PHW dengan pihak lain sangat penting kerana ia menjadi satu daripada strategi untuk membina kembali kehidupan mereka serta membuktikan kehadiran mereka diterima dalam masyarakat. Malah, dikatakan juga bahawa, komunikasi memberi pengaruh yang besar kepada PHW yang berada dalam situasi tertekan atau menghadapi masalah kesihatan seperti HIV positif (Reback et al., 2019). Namun begitu, tidak semua pihak yang berani atau sudi untuk berkomunikasi dengan PHW kerana risau dijangkiti oleh virus maut yang belum ditemui penawarnya sehingga kini. Komunikasi juga penting kepada PHW sebagai 'penawar' untuk mendapat sokongan sosial sekali gus dapat meningkatkan kesihatan mental dan fizikal (Fredrisken-Golden et al., 2014). Kegagalan mendapat komunikasi yang baik meletakkan PHW kepada risiko tinggi untuk terlibat dengan perkara-perkara negatif seperti mana yang sentiasa dilabel dan diberikan konotasi negatif oleh banyak pihak. Menurut Stotzer (2011), komunikasi dapat membantu mengurangkan tingkah laku berisiko PHW yang 
sering dikaitkan dengan aktiviti tidak bermoral seperti menagih dadah, pelacur, seks bebas atau dikaitkan dengan kumpulan Lesbian, Gay, Biseksual dan Transgender (LGBT).

Peluang komunikasi sama rata perlu diberikan kepada PHW kerana melaluinya banyak isu yang dapat difahami, terutamanya berkaitan kesihatan HIV positif itu sendiri. Namun dalam sesetengah budaya, golongan wanita tidak bebas memperkatakan isu kesihatan (terutamanya seksual) kerana dikaitkan dengan unsur taboo atau pelanggaran norma dalam masyarakat serta agama sebagaimana dipraktikkan di kebanyakan negara Islam (Bez \& Zihni, 2016). Larangan bercakap isu seksual menjadi lebih ketat atau dilarang apabila melibatkan wanita muda atau gadis remaja yang belum berkahwin. Hal ini dikatakan tidak 'manis' atau dianggap sebagai wanita murahan (Heise \& Alias; Aishah@Eshah, 2009), promiscuous, tidak malu, berpengalaman, curang dan gila seks (Aishah@Eshah, 2009). Dalam masyarakat Melayu sendiri, dilarang bercakap perkara berkaitan seksual dan larangan tersebut sangat dititikberatkan kerana menjadi sebahagian daripada warisan budaya sejak zaman berzaman (disiplin lisan). Pelanggaran larangan tersebut akan mengakibatkan kesan buruk (Nur Diyana Zamani \& Hasmidar, 2018). Apabila peluang komunikasi tidak seimbang, maka wujud situasi yang penuh dengan tekanan apabila melibatkan keadaan yang mengehadkan atau menjejaskan kehidupan harian seseorang individu seperti PHW atau penghidap penyakit kronik (Fearnley \& Boland, 2017). Tahap dan pola komunikasi antara ahli keluarga atau anggota masyarakat menjadi tegang apabila mereka merasakan diri tidak lagi berfungsi dengan sempurna. Keadaan bertambah tertekan apabila penyakit tersebut merupakan sejenis penyakit yang dipandang hina oleh masyarakat, berstigma dan diskriminasi seperti HIV positif dan AIDS. Dalam konteks dunia hari ini, isu-isu kesihatan sepatutnya dibincangkan dari semasa ke semasa untuk mengelak golongan seperti wanita daripada terus menjadi mangsa jangkitan HIV positif.

\section{Metod dan Kawasan Kajian}

Kajian mengenai cabaran dalam kalangan penghidap HIV positif wanita (PHW) ini telah dilakukan dengan menggunakan pendekatan kualitatif melalui kaedah temu bual secara mendalam untuk mendapatkan data primer. Kaedah temu bual mendalam menjadi pilihan utama kerana kajian HIV positif penuh dengan nilai kerahsiaan, stigma, diskriminasi dan bersifat sensitif. Bagi PHW sendiri, mereka lebih suka dengan kaedah 'bersembang santai' kerana tidak terlalu terikat dengan peraturan atau situasi formal seperti menggunakan set soal selidik. Seramai 20 orang informan wanita Melayu yang telah dijangkiti HIV positif terlibat dalam kajian ini. Kawasan kajian yang terlibat ialah di daerah Besut (Terengganu) dan tiga jajahan di negeri Kelantan, iaitu Pasir Puteh, Bachok dan Kota Bharu. Kajian ini hanya melibatkan penghidap HIV wanita sahaja tanpa melibatkan suami/pasangan mereka atas beberapa sebab yang tidak dapat dielakkan, antaranya belum bersedia untuk melibatkan suami/pasangan sendiri, telah berpisah atau suami/pasangan telah meninggal dunia (ibu tunggal).

Di samping itu, pemilihan lokasi ini juga dibuat kerana mengambil kira jumlah kes berisiko yang agak tinggi di kawasan ini yang turut dikenali sebagai kawasan 'pesisir'. Lokasi ini menjadi tumpuan warga asing yang bekerja sebagai nelayan terutamanya di jeti pendaratan ikan Lembaga Kemajuan Ikan Malaysia (LKIM) di Tok Bali (Kelantan) dan Kuala Besut 
(Terengganu). Nelayan asing terutamanya daripada negara Thailand, Myanmar dan Vietnam yang bekerja sebagai nelayan turut membawa bersama tabiat serta budaya tidak baik dari negara asal mereka seperti meminum minuman keras serta bahan terlarang seperti dadah. Golongan muda tempatan turut terlibat sama melepak serta bergaul dengan nelayan asing ini dan akhirnya ada dalam kalangan mereka turut dijangkiti dengan virus HIV positif melalui perkongsian jarum suntikan dadah yang tercemar dengan virus HIV positif. Akibatnya, virus HIV positif disebarkan kepada pasangan masing-masing tanpa disedari. Bagi menyokong dapatan utama ini, data sekunder berupa jurnal, statistik, laporan surat khabar atau laporan-laporan semasa turut digunakan.

\section{Hasil Kajian dan Perbincangan}

Hasil kajian mendapati, hampir kesemua informan yang ditemu bual mendedahkan mereka berhadapan dengan banyak cabaran setelah bergelar penghidap HIV positif. Cabaran yang diterima bukan sahaja menjejaskan kehidupan mereka sendiri, tetapi juga kepada pihak lain yang berhubung secara langsung atau tidak langsung dengan mereka. Selain distigma, didiskriminasi dan diberikan label negatif, informan turut mengakui mereka banyak memikirkan perkara-perkara negatif setelah dijangkiti virus HIV positif. Mereka memikirkan perkara negatif tersebut yang bukan dibuat secara sengaja, tetapi ia terjadi tanpa disedari dan tanpa dirancang. Pada akhirnya, keadaan tersebut telah banyak mempengaruhi kehidupan mereka. Antara perkara negatif yang difikirkan ialah 'HIV ialah AIDS', 'jangkitan maut', hanya 'menunggu mati', 'tidak boleh bekerja, berkahwin', 'dimandikan dengan klorok', 'kotor', 'hina' dan 'tiada orang berani mendekati'. Tindakan infoman yang memikirkan perkara-perkara negatif dalam tempoh masa yang lama akhirnya menyebabkan kehidupan harian mereka terganggu kerana terlalu membiarkan situasi negatif menguasai diri.

Jadual 1 Profil Informan HIV Positif Wanita

\begin{tabular}{cccccl}
\hline Informan & $\begin{array}{c}\text { Umur } \\
\text { (Tahun) }\end{array}$ & $\begin{array}{c}\text { Status Perkahwinan } \\
\text { (Bil. Anak) }\end{array}$ & $\begin{array}{c}\text { Jangkitan } \\
\text { (Tahun) }\end{array}$ & Pendidikan & Pekerjaan \\
\hline 1 & 28 & Berkahwin (2) & 7 & Tingkatan 1 & Suri Rumah \\
2 & 30 & Berkahwin (2) & 6 & Tingkatan 3 & Suri Rumah \\
3 & 33 & Berkahwin (2) & 9 & SPM & Tukang Jahit, Butik \\
4 & 34 & Ibu Tunggal (1) & 5 & SPM & Pengasuh, Buat Kuih \\
5 & 36 & Ibu Tunggal (1) & 14 & SPM & Pengasuh \\
6 & 37 & Ibu Tunggal (1) & 2 & SPM & Tukang Jahit, Butik \\
7 & 37 & Ibu Tunggal (1) & 6 & Tingkatan 3 & Tukang Sapu \\
8 & 37 & Ibu Tunggal (2) & 10 & SPM & Peniaga, Kerja Kampung \\
9 & 37 & Berkahwin (2) & 8 & SPM & Stesen Minyak \\
10 & 38 & Berkahwin (2) & 8 & SPM & Tukang Sapu \\
11 & 38 & Berkahwin (1) & 5 & SPM & Kedai Makan \\
12 & 39 & Berkahwin (1) & 5 & SPM & Suri Rumah \\
13 & 39 & Ibu Tunggal (1) & 7 & SPM & Pembantu Tadika \\
14 & 40 & Ibu Tunggal (1) & 13 & SPM & Menoreh Getah \\
15 & 41 & Berkahwin (2) & 5 & Degree & Cikgu Tadika \\
16 & 43 & Ibu Tunggal (1) & 15 & Tingkatan 3 & Tukang Jahit \\
17 & 45 & Ibu Tunggal (1) & 5 & SPM & Tidak Bekerja
\end{tabular}


Jurnal Pengajian Melayu - JOMAS, Jilid 32(2), 2021: 74-93

\begin{tabular}{lllccl}
18 & 49 & Ibu Tunggal (2) & 3 & SPM & Pertubuhan (NGO) \\
19 & 51 & Ibu Tunggal (2) & 8 & Darjah 6 & Menoreh Getah, Buat Kuih \\
20 & 53 & Ibu Tunggal (1) & 15 & SPM & Tukang Jahit \\
\hline
\end{tabular}

Sumber: Kerja Lapangan

Dalam kajian ini, seramai 20 orang informan telah ditemu bual dan mereka berumur antara 28 hingga 55 tahun. Dalam konteks tempoh jangkitan, paling lama dijangkiti ialah 15 tahun dan paling baru pula ialah 2 tahun. Status perkahwinan informan semasa ditemu bual ada yang masih dalam ikatan perkahwinan (majoriti dengan suami baru) dan ada yang berstatus ibu tunggal kerana telah berpisah dengan suami/pasangan (berpisah dan mati). Di samping itu, latar belakang pendidikan informan berbeza-beza, paling ramai pada peringkat Sijil Pelajaran Malaysia (SPM), dan selebihnya Menengah Rendah (Tingkatan 1 hingga Tingkatan 3), Sekolah Rendah. Terdapat seorang infoman yang mempunyai kelayakan akademik peringkat Ijazah Sarjana Muda (Degree). Jenis pekerjaan informan juga berbeza antara satu sama lain walaupun dalam kategori sama, iaitu kategori kerja-kerja kampung dengan kadar upah pada peringkat sederhana (lihat Jadual 1).

\section{Cabaran Stigma, Diskriminasi dan Label}

Cabaran paling utama, terbesar dan sinonim dengan penghidap HIV positif ini adalah cabaran stigma, diskriminasi dan label negatif. Jarang ada penghidap HIV positif sama ada lelaki mahupun wanita yang terlepas daripada cabaran ini. Perkara ini dikatakan sedemikian kerana, HIV positif itu sendiri sebenarnya penyakit yang penuh dengan nilai kerahsiaan, stigma, diskriminasi, label serta konotasi negatif. Oleh sebab itu, ada informan yang sangat takut sekiranya status kesihatan mereka diketahui umum kerana kesannya sangat teruk. Malah, ada juga informan yang lebih risau terhadap stigma, diskriminasi dan label negatif berbanding dengan virus HIV itu sendiri. Sebagai mana diketahui umum, cabaran ini boleh berlaku setiap masa, di mana-mana dan oleh sesiapa sahaja tanpa mengira siapa penghidap HIV positif. Kesannya, tidak dapat digambarkan dengan kata-kata dan yang pasti kehidupan boleh terjejas secara holistik.

Ketakutan yang dialami oleh informan bukan dibuat-dibuat, tetapi benar-benar berlaku. Menurut Unger \& Collins (2005), perkataan 'positif' daripada HIV dianggap fasa atau peristiwa yang telah mengubah kehidupan seseorang penghidap. Kehidupan benar-benar berubah setelah mereka bergelar penghidap HIV positif kerana ramai pihak semakin menjauhkan diri daripada mereka, peluang juga semakin mengecil. Malah, penghidap sendiri mula mengasingkan diri, berkurung di dalam rumah/bilik, sentiasa dalam keadaan bersedih, kecewa, takut, marah dan tertekan kerana tidak pernah menduga dijangkiti oleh virus yang ditakuti oleh semua orang. Cabaran stigma, diskriminasi dan label negatif dihadapi oleh informan dipecahkan kepada tiga bahagian, iaitu (1) oleh ahli keluarga dan anggota masyarakat, (2) kakitangan perubatan (semasa mendapatkan rawatan), dan (3) majikan serta rakan sekerja. 


\section{Stigma, Diskriminasi, Label Negatif oleh Ahli Keluarga dan Masyarakat}

Ahli keluarga seperti ibu bapa, adik-beradik, anak-anak dan suami/pasangan menjadi pilihan utama informan untuk berkongsi masalah yang dihadapi oleh mereka. Sebagaimana diketahui umum, HIV positif bukan berita gembira, tetapi kejutan duka yang mengganggu aturan kehidupan harian informan. Oleh sebab itu, informan mencari pihak paling rapat dan dipercayai untuk menceritakan perkara yang berlaku kepada mereka seperti ahli keluarga. Ahli keluarga juga diyakini dapat memberi sokongan dan menerima keadaan informan dalam apa-apa jua keadaan termasuk selepas bergelar penghidap HIV positif. Namun begitu, sebenarnya ada juga ahli keluarga informan tidak dapat menerima kenyataan bahawa ada dalam kalangan mereka yang dijangkiti oleh HIV positif. Sehubungan dengan itu, tindakan mendedahkan status kesihatan diri termasuk kepada ahli keluarga sendiri dianggap situasi 'pertaruhan' kerana mereka tidak tahu siapa sebenarnya yang dapat menerima dan tidak dapat menerima keadaan kesihatan mereka.

Situasi dan pengalaman serupa turut diceritakan oleh kesemua informan dalam kajian ini apabila ada yang distigma, didiskriminasi dan diberikan label negatif sehingga hubungan mereka bermasalah. Keadaan tersebut bukan sahaja menimbulkan masalah komunikasi, tetapi menjejaskan hubungan kekeluargaan antara informan dengan ahli keluarga yang lain, terutamanya adik-beradik. Pengalaman ini diceritakan oleh seorang daripada informan yang terlibat, iaitu mengenai hubungan dengan adik-beradiknya yang bermasalah. Semuanya disebabkan oleh sikap adik-beradik yang tidak boleh menerima kenyataan. Selain itu, masyarakat setempat turut memandang hina kepada pesakit HIV positif apabila mereka sudah mengetahui keadaan diri informan. Berikut merupakan petikan kata-kata daripada Informan 8 berkaitan masalah dalam hubungan adik-beradiknya.

“...reaksi adik-beradik saya lepas tahu memang mereka terkejut, ada sorang adik saya tak boleh terima kenyataan. Jadinya hubungan saya dengan dia sekarang tidak macam adik- beradik dah, semua orang kampung tahu pun sebab dia yang sebar cerita. Dia pesan juga dekat anak-anak dia jangan berkawan dan bermain dengan anak saya, saya dengan suami saya ada AIDS, hisap dadah.... sikap dia saya memang tak boleh terima dan marah, dia marah libatkan anak-anak saya, kata macam-macam, dia nak hina saya boleh takde masalah, 10 kali hina pun takpe, tapi jangan libatkan anak-anak saya, mereka tidak bersalah..."

Berdasarkan pendedahan yang dibuat oleh informan, sebenarnya tidak lain dan bukan, mereka memerlukan sokongan sosial. Sokongan sosial bukan sahaja dapat menghalang stigma, diskriminasi dan label negatif, tetapi sangat penting untuk penyesuaian psikologi. Informan juga boleh meningkatkan kesihatan fizikal dan emosi, meningkatkan motivasi untuk rawatan, tingkah laku menjaga diri sendiri dan mencegah transmisi jangkitan. Dengan adanya sokongan sosial, informan dapat membina dan meneruskan kehidupan harian mereka selain merasakan diri diterima dan rasa masih diberikan kepercayaan. Malah, telah terbukti bahawa, orang yang hidup dengan HIV positif mempunyai kualiti kehidupan yang lebih baik dengan sokongan sosial yang diterima. Sama juga seperti pesakit kronik lain, sokongan sosial mampu meredakan tekanan dalam diri orang yang hidup dengan HIV positif dan menggalakkan rasa kesejahteraan emosi 
(Kalichman, et al., 2003). Namun begitu, mendapatkan sokongan sosial bukan perkara mudah kerana dianggap sebagai pertaruhan bagi kebanyakan penghidap serta memerlukan mereka mendedahkan status kesihatan kepada orang lain (Huber, 1996; Kalichman et al., 2003).

Situasi serupa juga dilakukan oleh Informan 17 apabila hanya mendedahkan status kepada pihak yang betul-betul dipercayai sahaja atau langsung tidak mendedahkan status kesihatan mereka. Tindakan yang diambil oleh informan adalah untuk melindungi diri sendiri daripada terus menjadi mangsa stigma, diskriminasi dan label negatif. Dengan menyembunyikan status kesihatan diri memberi peluang kepada informan menjalani kehidupan seperti biasa walaupun secara dalaman sebenarnya mereka sangat kecewa, sedih dan tertekan.

\section{Informan 17: \\ "...hubungan saya dengan adik-beradik baik takde masalah sebab masing- masing tidak tahu status saya, memang tidak tahu. Semua buat macam biasa, buat ceria. Kalau adik-beradik tahu, tak tahu lah saya apa nak kata. Tak tahu sama ada mereka boleh terima atau tidak, itu yang saya dok fikir dari dulu. Setakat hari ini saya belum terbuka hati nak bagitahu, belum boleh cerita. Tidak tahu yang mana satu boleh percaya..."}

Selain ahli keluarga, informan turut berhadapan cabaran stigma, diskriminasi dan label negatif daripada anggota masyarakat lain seperti jiran dan rakan-rakan. Hasil temu bual dilakukan ke atas informan mendapati bahawa, ada dalam kalangan mereka yang tidak lagi bertegur sapa dengan jiran tetangga kerana dituduh dengan pelbagai tuduhan yang tidak sedap didengar. Begitu juga hubungan dengan rakan-rakan sudah berubah apabila informan bergelar penghidap HIV positif. Jika sebelum ini informan bebas ke rumah jiran dan rakan-rakan mereka, tetapi kini tidak lagi kerana ramai yang mengelak daripada berjumpa dan bersembang dengan informan. Malah, perkara yang menyedihkan lagi apabila jiran-jiran terdekat tidak lagi menjemput mereka hadir ke majlis-majlis keraian yang diadakan. Oleh sebab itu, informan merasakan banyak peluang dalam kehidupan mereka sudah tiada lagi berbanding sebelum dijangkiti HIV positif. Menurut Informan 1:

Informan 1:

“...status saya ramai sudah tahu, orang sekeliling pun dah mula bercakapcakap. Lepas tu pula, nurse selalu datang ke rumah saya bawa susu untuk anak saya, kadang-kadang ambulan juga datang. Jiran pernah tanya kenapa anak tidak minum susu badan, saya kata susu saya tidak keluar dan nurse minta saya minum susu ini. Padahal masa tu bahaya kalau saya bagi anak saya susu badan sebab risiko tinggi. Lama-lama lepas itu semua jiran tahu saya ada sakit nie, dulu pernah juga jiran-jiran datang bersembang di rumah saya, lepas dia tahu saya ada sakit ini, makin kurang dah. Saya sendiri pun kalau takde perkara penting saya tak pergi sangat rumah jiran, setakat sajesaje nak pergi memang saya tak pergi. Pernah jiran buat kenduri, dia tidak panggil dah walaupun dekat depan mata, kalau sekali mungkin boleh kata 
dia tidak perasan, tapi kalau banyak kali memang dia tidak mahu jemput saya. Saya selepas dia layan saya macam tu, saya pun nekad untuk kurangkan aktiviti luar sebab tidak mahu orang lain juga tahu keadaan diri saya..."

Pendedahan informan mengenai perlakuan stigma, diskriminasi dan label negatif oleh ahli keluarga dan anggota masyarakat turut membuktikan kajian-kajian yang telah dilakukan sebelum ini. Malah, tindakan informan memilih untuk mendedah atau tidak mendedahkan status dalam diri mereka juga terbukti benar. Misalnya, kajian oleh Nachega, et al. (2012) mendedahkan, seseorang penghidap sukar untuk mendedahkan status kesihatannya kerana tidak mahu terus menerus dipandang hina oleh ahli keluarga dan anggota masyarakat. Banyak aspek diambil kira sebelum mendedahkan status HIV positif, antaranya ialah (1) diskriminasi sosial, (2) hubungan masa hadapan, (3) hubungan semasa, (4) kemerosotan reputasi, (5) risiko kehilangan pekerjaan, (6) kehilangan ahli keluarga, dan (7) isu kesihatan (rawatan, insurans).

\section{Stigma, Diskriminasi, Label Negatif oleh Kakitangan Perubatan}

Sebagaimana dijelaskan pada bahagian awal penulisan, stigma, diskriminasi dan label negatif bukan berlaku dalam lingkungan keluarga sahaja, tetapi juga luar lingkungan keluarga. Dalam kajian ini mendapati bahawa, informan turut melalui cabaran yang sama semasa mendapatkan rawatan kesihatan di klinik mahupun hospital. Kakitangan kesihatan seperti jururawat atau doktor walaupun mereka dilatih untuk mengurus kes-kes seperti informan dengan etika kerja yang tinggi, tetapi sebenarnya ada juga dalam kalangan mereka yang tidak beretika (terutamanya jururawat pelatih dan doktor muda). Pendedahan ini dibuat oleh informan berdasarkan kepada pengalaman mereka selama bergelar penghidap HIV positif. Menurut Informan 20, pernah suatu ketika kakitangan kesihatan melayan dirinya seperti orang yang tiada harga diri, menggunakan perkataan yang sangat menyinggung perasaan dan beranggapan informan seperti orang yang 'kotor'. Informan mengakui sangat kecewa, marah dan sedih dengan layanan yang diberikan. Akhirnya, informan mengambil keputusan tidak lagi mendapatkan rawatan di klinik biasa, sebaliknya memilih rawatan di hospital besar, walaupun lokasinya jauh dari kediaman mereka. Menurut informan lagi, layanan doktor biasa dan doktor pakar juga berbeza walaupun kedua-duanya bergelar doktor dan menjadi pihak yang paling dipercayai oleh mereka. Menurut informan lagi:

Informan 20:

“...saya kalau rawatan saya tidak pergi ke Klinik Kesihatan (KK), tapi terus ke hospital besar sebab layanan berbeza. Pernah satu kali saya pergi ke klinik dah dilayan sangat teruk, dia tanya saya seolah-olah saya nie sangat 'kotor', teruk dan jahat. Dia tanya saya, 'awak orang mana? Awak orang Golok (Thailand) ker? Masa itu saya terus menangis,... Lepas saya kena teruk dengan nurse, saya tak pergi lagi ke KK, tambahan pula KK ramai orang kampung, takut dalam ramai-ramai ada yang kita kenal atau dia kenal kita. Kadang-kadang nurse kampung mulut mereka boleh 
tahan juga, suka bercerita kepada orang lain... Doktor biasa dan pakar cara layanan pun berbeza, walaupun mereka layan dan rawat kita tidak pakai sarung tangan, tapi selepas itu terus berlari basuh tangan. Masa itu saya dah perasan, nampak sangat penerimaan mereka kepada kita macam mana. Doktor pakar takde macam tu. Memang mereka layan baik, cakap baik tetapi perbuatan mereka tu macam tidak kena..."

Situasi yang diceritakan oleh Informan 20 menggambarkan kakitangan hospital yang dilatih dengan etika kerja yang baik dan tinggi, namun tidak semua kakitangan yang faham dan mengamalkannya. Malah, tindakan oleh sesetengah kakitangan kesihatan ini meletakkan para penghidap HIV positif dalam situasi bahaya dan boleh menyebabkan mereka enggan mendapat rawatan kesihatan. Apabila informan atau penghidap HIV positif mengelak daripada mendapatkan rawatan kesihatan, mereka berada pada risiko tinggi untuk menyebarkan jangkitan kepada pihak lain dan mereka sendiri mudah terdedah kepada pelbagai jenis penyakit berbahaya lain. Seperti yang diketahui umum, penghidap HIV positif tidak boleh mengelak daripada mendapat rawatan kesihatan kerana rawatan kesihatan sahaja boleh membantu mereka mengekalkan tahap kesihatan dan bertahan untuk hidup lebih lama. Tambahan lagi, penghidap HIV positif tidak boleh dipisahkan dengan rawatan dan aspek kesihatan.

\section{Stigma, Diskriminasi, Label Negatif oleh Majikan dan Rakan Sekerja}

Dalam konteks pekerjaan, terdapat informan yang mendedahkan peluang mereka semakin berkurangan kerana tiada majikan yang sanggup mengambil pekerja dalam kalangan penghidap HIV positif kerana pelbagai alasan seperti takut kehilangan pelanggan dan bimbang dijangkiti. Terdapat juga informan yang berhenti secara sukarela dan mencari pekerjaan lain kerana bimbang status kesihatan diketahui oleh pihak majikan serta rakan sekerja lain. Apabila berhenti kerja, informan sebenarnya tidak lagi mempunyai peluang seperti seperti sebelum dijangkiti HIV positif. Dalam kajian ini, jenis-jenis pekerjaan informan boleh dipecahkan kepada tiga kategori, iaitu Kategori 1, Kategori 2 dan Kategori 3 (lihat Jadual 2).

Jadual 2 Jenis / Kategori Pekerjaan Informan

\begin{tabular}{lc}
\hline Jenis / Kategori Pekerjaan & Anggaran Pendapatan (Bulanan) \\
\hline Kategori 1; & \\
Pengasuh & RM 150.00 - RM 300.00 \\
Pembuat Kuih & \\
Penoreh Getah & \\
Peniaga Kedai Runcit & \\
Tukang Cuci (Cleaner) & \\
\hline Kategori 2; & \\
Pembantu Tadika & \\
Penjaga Pertubuhan Kebajikan (NGO) & \\
Tukang Jahit Butik & RM 350.00 - RM 900.00 \\
Pengusaha Pusat Asuhan Kanak-Kanak & \\
\hline
\end{tabular}




\begin{tabular}{l}
\hline Pembantu Stesen Minyak \\
Pembantu Kedai Makan \\
\hline Kategori 3*; \\
Suri Rumah \& Tidak Bekerja
\end{tabular}

Nota: *Bantuan dan ehsan adik-beradik, suami

Pekerjaan Kategori I dikategorikan sebagai kerja 'biasa-biasa' kerana bayaran upah yang diterima sederhana dan 'cukup-cukup makan', iaitu antara RM150 hingga RM300 sebulan. Pekerjaan Kategori 2 pula lebih stabil dengan purata gaji atau kadar upah antara RM350 hingga RM900 sebulan, manakala Kategori 3 pula pekerjaan dalam lingkungan keluarga dan tidak mempunyai sumber pendapatan tetap. Pendapatan atau sumber kewangan bergantung kepada ehsan suami/pasangan, adik-beradik, ibu bapa serta bantuan daripada Jabatan Kebajikan Masyarakat (JKM). Walaupun pekerjaan informan dianggap 'biasa-biasa', namun, mereka tetap bersyukur dengan keadaan hidup mereka. Di sebalik jenis pekerjaan yang dilakukan oleh informan, sebenarnya mereka berhadapan dengan pelbagai cabaran stigma, diskriminasi dan label negatif.

Kategori pekerjaan yang dipaparkan dalam Jadual 2 sebenarnya merupakan pekerjaan kedua atau ketiga informan. Terdapat juga informan yang masih kekal dengan pekerjaan lama mereka walaupun dengan status HIV positif kerana tiada orang yang tahu keadaan kesihatan informan. Menurut Informan 11, sebelum melakukan kerja yang ada sekarang ini, beliau pernah bekerja dengan orang lain. Namun, disebabkan oleh status kesihatan suami yang juga dijangkiti HIV positif, menyebabkan dia dibuang kerja. Menurut informan lagi, pada mulanya majikan dan rakan sekerja tidak tahu status HIV positif yang dihadapinya, lama kelamaan terbongkar juga. Setelah status kesihatan terbongkar, layanan oleh majikan dan rakan sekerja terhadap informan semakin berubah dan akhirnya diberhentikan kerja. Menurut informan:

Informan 11:

“...asalnya orang kampung tahu suami saya sakit sebab HIV/AIDS. Lama-lama orang kerja sekali dengan saya pun tahu juga suami saya sakit sebab penyakit tu. Masa itu saya kerja buat kuih. Dua bulan selepas kes suami saya terbongkar, majikan baru tahu, atau dia dah tahu sebelum itu lagi saya pun tidak pasti. Majikan jumpa saya dan pesan kepada saya, lepas ini tidak perlu datang kerja dah, takut berjangkit. Dia cakap macam tu, alasan lain dia kata tidak mahu ramai pekerja. Saya pernah tanya dia kenapa, mula-mula dia bagi macam-macam alasan, akhirnya dia mengaku ramai orang tidak mahu membeli kuihnya. Lepas dia serah duit gaji last, dia kata cari kerja lain..."

Informan yang bermasalah dengan pekerjaan dan sumber kewangan mengakui bahawa mereka sangat memerlukan pekerjaan kerana banyak kos yang perlu mereka tanggung, seperti mendapatkan rawatan kesihatan, sumber makanan dan air minuman yang bersih, kediaman atau tempat tinggal yang selamat. Kos dan tuntutan hidup bukan untuk diri sendiri tetapi termasuk juga tuntutan untuk anak-anak kecil serta ibu bapa yang berada di bawah tanggungjawab pesakit. Mendapatkan pekerjaan dan sumber kewangan juga bukan perkara mudah bagi informan kerana dipengaruhi oleh pelbagai faktor seperti pengalaman, kemahiran, tahap pendidikan dan peluang 
pekerjaan sendiri yang semakin berkurangan. Latar belakang pendidikan (lihat Jadual 1) informan dalam kajian ini sendiri sememangnya pada tahap rendah dan sederhana. Maka tidak hairanlah sekiranya mereka tidak mendapat peluang pekerjaan yang baik. Peluang semakin tertutup apabila informan disahkan menghidap HIV positif dan berisiko dibuang kerja oleh majikan serta kehilangan sumber kewangan bagi mereka yang sudah mempunyai pekerjaan sekiranya status kesihatan mereka terbongkar (Forouzan et al., 2013). Namun begitu, hari ini sebenarnya banyak peluang pekerjaan lain yang boleh diceburi oleh PHW tanpa perlu berhadapan dengan pihak luar secara fizikal, antaranya ialah perniagaan secara dalam talian. Menurut Norsafani Maisarah Mohd Nawi et al. (2020), peluang perniagaan secara dalam talian menjadi platform terbaik kepada golongan wanita kerana menawarkan pelbagai kemudahan. Malah, platform ini menjadi pilihan untuk mereka memasarkan produk keluaran sendiri atau produk daripada pembekal lain.

Informan yang berpisah atau kehilangan suami/pasangan (ibu tunggal) mempunyai tanggungjawab besar kerana segala urusan dilakukan sendiri. Tambahan lagi, jarang ada pihak lain yang sanggup mengambil alih tugasan penghidap HIV positif apabila kehilangan suami/pasangan (Parker et al., 2003) seperti dialami informan dalam kajian ini. Informan juga mengakui bahawa, sebenarnya mereka terlibat dengan pekerjaan untuk melupakan perkaraperkara negatif yang berlaku ke atas diri mereka termasuklah stigma, diskriminasi, label negatif, masalah suami yang terlibat dengan kegiatan tidak bermoral dan cemuhan orang sekeliling (Mashrom Muda, 2018). Apabila sudah penat bekerja, informan hanya ingin balik berehat dan tiada ruang memikirkan masalah. Namun begitu, tindakan oleh sesetengah majikan dan rakan sekerja yang melayan informan dengan cara tidak sepatutnya menyebabkan mereka sentiasa dalam ketakutan. Malah, ada dalam kalangan informan mengambil pendekatan menyembunyikan status kesihatan mereka, 'menipu' dan 'berlakon' sihat kerana tidak mahu diberhentikan kerja.

\section{Kesimpulan}

Apabila dijangkiti HIV positif, jarang ada penghidap yang tidak terkesan sama ada secara fizikal mahupun secara emosi dan psikologi. Cabaran dihadapi adalah berbeza setiap orang penghidap, namun paling sinonim ialah stigma, diskriminasi dan label bersifat negatif sama ada oleh ahli keluarga sendiri mahupun anggota masyarakat secara umumnya. Cabaran ini juga dilihat sangat sukar dielak oleh penghidap HIV positif terutamanya wanita kerana telah menjadi sebahagian daripada kepercayaan serta mitos kebanyakan anggota masyarakat. Apabila menyebut sahaja penghidap HIV positif sama ada lelaki mahupun wanita, stigma, diskriminasi dan label negatif menjadi perkara pertama difikirkan oleh penghidap kerana mereka tahu kesannya lebih teruk daripada jangkitan virus HIV itu sendiri. Selain masalah kesihatan yang semakin menurun, ketiga-tiga cabaran ini juga berupaya menjejaskan kesemua aspek kehidupan penghidap. Oleh sebab itu, dikatakan bahawa cabaran ini adalah cabaran utama serta terbesar dihadapi oleh penghidap HIV positif. Namun begitu, penghidap wanita sebenarnya berupaya membina kembali kehidupan mereka apabila mendapat sokongan daripada semua pihak. Penghidap wanita juga tidak selamanya berada dalam kesedihan, marah dan perasaan tertekan apabila mereka diberikan peluang sama rata seperti individu sihat lain. Malah, mereka boleh mencapai tahap kesejahteraan 
hidup lebih baik berbanding individu normal lain seperti sukar mendapat penyakit lain dan dapat bertahan hidup lebih lama walaupun dengan virus HIV positif dalam diri terutamanya selepas mendapat vaksin anti-retroviral.

\section{Rujukan}

Adeyemo, S., Olorunkoya, O.G., Chinelo, O.L., Babalola, G. \& Abojei, C.O. (2019). Prevalence and psychosocial correlates of suicidal ideation among adolescents living with HIV in Southwestern Nigeria, West Africa. HIV \& AIDS. International Journal of HIV-Related Problems, 18(4), 273-278. https://doi.org/10.5114/hivar.2019.85949.

Aishah @ Eshah Mohamed. (2006). Gender dan Mod Jangkitan HIV/AIDS: Suatu Analisis Sosiobudaya. In Norhaslina Hassan (pnyt.), Dinamika Masyarakat Bandar Malaysia: Ke Arah Kualiti Hidup Mapan (pp. 39-55). Kuala Lumpur: Penerbit Universiti Malaya.

Aishah @ Eshah Mohamed. (2009). Wanita, Hak dan HIV/AIDS. In. Aishah @ Eshah Mohamed, Sulong Muhamad, Zaidah Mustapha \& Rokiah Ismail (pnyt.), Peranan, Hak dan Penyesuaian Hidup Wanita di Malaysia (pp. 85-98). Bangi: Pusat Pengajian Sosial, Pembangunan dan Persekitaran, Universiti Kebangsaan Malaysia.

Badariah Mohd Saad, Peck-Leong Tan \& Geetha Subramaniam. (2015). Implication of HIV/AIDS knowledge on quality of life of young women in Malaysia. Journal of Procedia Social and Behavioral Science, 202(2015), 218-226. Retrieved from https://www.sciencedirect.com/science/article/pii/ S1877042815048739.

Bez, Y. \& Zihni, M. (2016). Cultural factors in the treatment of sexual dysfunction in muslim client. Current Sexual Health Report, 8(2), 57-63. Retrieved from https://link.springer.com/article/10.1007/s11930-016-0068-z.

Fearnley, R. \& Boland, J.W. (2017). Communication and support from health-care professionals to families, with dependent children, following the diagnosis of parental life-limiting illness: A systematic revgiew. Journal of Palliative Medicine, 31(3): pp. 212-222. Retrieved from https://pubmed.ncbi.nlm.nih.gov/27383635/.

Fee, E. \& Parry, M. (2008). Jonathan mann, HIV/AIDS and human right. Journal of Public Health Policy, 29(1): 54-71. Retrieved from https://www.jstor.org/stable/40207166?seq=1\#metadata_info_tab_contents.

Forouzan, A.S., Shushtari, Z.J., Sajjadi, H., Salimi, Y. \& Dejman, M. (2013). Social support network among people living with HIV/AIDS in Iran. Journal of AIDS Research and Treatment, pp. 1-7. Retrieved from https://www.hindawi.com/journals/art/2013/715381/.

Fredrisksen-Goldsen, K.I., Cook-Daniels, L. Hyun-Jun, K., Erosheva, E.A., Emlet, C.A., HoyEllis, C.P., Goldsen, J. \& Muraco, A. (2014). Physical and Mental Health of Transgender 
Older Adults: An At-Risk and Underserved Population. Journal of The Gerontologist, 54(3), 488-500. Retrieved from https://pubmed.ncbi.nlm.nih.gov/23535500/.

Herek, G.M. (2002). Thinking about AIDS and stigma: A psyhologist's perspective. The Journal of Law, Medicine \& Ethics, 30(4), 594-607. Retrieved from https://journals.sagepub.com/doi/10.1111/j.1748-720X.2002.tb00428.x.

Infante, C., Aggleton, P. \& Pridmore, P. (2009). Forms and determinants of migration and HIV/AIDS-related stigma on the Mexican-Guatemalan border. Journal of Qualitative Health Research, 19(12), pp. 1656-1668. https://journals.sagepub.com/doi/10.1177/ 1049732309353909.

Kalichman, S.C., DiMarco, M., Austin, J., Luke, W. \& DiFonzo, K. (2003). "Stress, social support, and HIV-status disclosure to family and friends among HIV-positive men and women," Journal of Behavioral Medicine, 26(4), pp. 315-332. Retrieved from https://pubmed.ncbi.nlm.nih.gov/12921006/.

Loutfy, M., Khosla, R. \& Narasimshan, M. (2015). Advancing the sexual and reproductive health and human right of women living with HIV. Journal of The International AIDS Society, 18(5), 20760. Retrieved from https://pubmed.ncbi.nlm.nih.gov/26643465/.

Mashrom Muda \& Rahimah Abdul Aziz. (2018). Jangkitan HIV Positif Dalam Kalangan Penghidap Wanita: Pasrah atau Perkasa Diri. Dlm. Rahimah Abdul Aziz, Mohamad Fauzi Sukimi \& Nur Hafizah Yusoff (pnyt.), Malaysia Pembangunan Negara dan Kerencaman Isu Sosial (pp. 73-101). Bangi: Penerbit Universiti Kebangsaan Malaysia.

Mashrom Muda. (2018). Wanita dan Jangkitan HIV Positif: Kualiti Kehidupan dan Pemerkasaan Diri. Tesis Ijazah Doktor Falsafah. Universiti Kebangsaan Malaysia.

Mashrom Muda. (2019). Pandangan pesakit wanita HIV terhadap kematian. Malaysian Journal of Society and Space, 15(4), 206-219. Retrieved from https://ejournal.ukm.my/gmjss/article/view/36210.

Mbonu, N. C., den Borne, B. V. \& De Vires, N. K. (2010). Gender-related power differences, belief and reactions towards people living with HIV/AIDS: An urban study in Nigeria. BMC Public Health, 10(334), 1 - 10. Retrieved from https://bmcpublichealth.biomedcentral.com/articles/10.1186/ 1471-2458-10-334.

Mukolo, A., Blevins, M., Victor, B., Vaz. L.M.E., Sidat, M. \& Vergara, A. (2013). Correlates of social exclusion and negative labeling and devaluation of people living with HIV/AIDS in rural settings: evidence from a general household survey in Zambézia province, Mozambique. PLoS One Journal, 8(10),: e75744. Retrieved from https://journals.plos.org/plosone/article?id=10.1371/journal.pone.0075744. 
Nachega, J.B., Morroni, C., \& Zuniga, J.M. (2012). HIV-related stigma, isolation, discrimination, and serostatus: a global survey of 2035 HIV-infected adults. Journal of The International Association of Physicians in AIDS Care, 11(3), pp. 172-178. https://doi.org/10.1177/1545109712436723.

Nik Shahrizan Nik Mad, Marzudi Md Yunus \& Muhammad Shamsinor Abdul Aziz. (2020). Kesejahteraan Subjektif: Halangan dan Cabaran Peserta Program Mikro Kredit Amanah Ikhtiar Malaysia Cawangan Kepong, Wilayah Selangor dan Kuala Lumpur Tengah. Jurnal Pengajian Melayu/Journal of Malay Studies (JOMAS), 31 (1), pp. 20-35.

Norsafani Maisarah Mohd Nawi, Nur Yuhanis Mohd Nasir \& Kim Keum Hyun. (2020). Tingkah Laku Peniaga Wanita Melayu Dalam Talian: Sorotan Literatur dan Teori. Jurnal Pengajian Melayu/Journal of Malay Studies (JOMAS), 31 (1), pp. 61-75.

Nur Diyana Zamani \& Hasmidar Hassan. (2018). Bahasa Pantang Larang Masyarakat Melayu dan Hubungannya dengan Prinsip Relevans Kognitif dan Prinsip Relevans Komunikatif. Jurnal Pengajian Melayu/Journal of Malay Studies (JOMAS), 29 (1), pp. 118-155.

Office on Women's Health. (2021, 8 April). Women and HIV. Retrieved from https://www.womenshealth.gov/hiv-and-aids/women-and-hiv.

Parker, R., \& Aggleton, P. (2003). HIV and AIDS-related stigma and discrimination: A conceptual framework and implications for action. Social Science and Medicine, 57(1), pp. 13-24. Retrieved from https://pubmed.ncbi.nlm.nih.gov/12753813/.

Puri, M., Tamang, J. \& Shah, I. (2010). Exploring the nature and reasons associated with sexual violence within marriage among young women in Nepal. Journal of Interpersonal Violence, 25(10), pp. 1873-1892. Retrieved from https://journals.sagepub.com/doi/10.1177/0886260509354514.

Quinn, T.C. \& Overbaugh, J. (2005). HIV/AIDS in women: an expanding epidemic. Journal of Science, 308(5728), pp. 1582-1583. Retrieved from https://science.sciencemag.org/content/308/5728/1582.long.

Reback C.J., Clark, K., Fletcher, J.B. \& Holloway, I.W. (2019). A Multilevel Analysis of Social Network Characteristics and Technology Use on HIV Risk and Protective Behaviors among Transgender Women. Journal of AIDS Behavior, 23(5), pp. 1353-1367. Retrieved from https://www.ncbi.nlm.nih.gov/pmc/articles/PMC6511286/.

Shamos, S., Hartwig, K. A. \& Zindela, N. (2009). Men's and women's experiences with HIV and stigma in Swaziland. Qualitative Health Research, 19(12), 1678-1689. Retrieved from https://journals.sagepub.com/doi/10.1177/1049732309353910.

Shrestha, R. \& Copenhaver, M.M. (2016). Association between intimate partner violence women and HIV-risk behavior: findings from the Nepal demographic health survey. 
Jurnal Pengajian Melayu - JOMAS, Jilid 32(2), 2021: 74-93

Violence Against Women, 22(13), pp. 1-21. Retrieved from https://journals.sagepub.com/doi/10.1177/1077801216628690.

Siegel, K. \& Lekas, H.M. (2002). AIDS as a chronic illness: Psychosocial implications. AIDS Journal, 16(4), pp. 69-76. Retrieved from https://journals.lww.com/aidsonline/Fulltext/2002/16004/AIDS_as_a_chronic_illness psychosocial.10.aspx.

Singh, A.R. \& Singh, S.A. (2008). Diseases of poverty and lifestyle, well-being and human development. Journal of Mens Sana Monographs, 6(1), 187-225. Retrieved from https://www.ncbi.nlm.nih.gov/pmc/articles/PMC3190550/.

Stotzer, R.L. (2011). Family Cohesion among Hawai 'i's Māhūwahine. Journal of GLBT Family Studies, 7(5), pp. 424-435. https://www.tandfonline.com/doi/abs/10.1080/1550428X. 2011.623935.

The Joint United Nations Programme on HIV/AIDS. (2021, 7 March). Global HIV \& AIDS statistic - Fact sheet. Retrieved from https://www.unaids.org/en/resources/fact-sheet.

Unger, H.V. \& Collins, P.Y. 2005. Transforming the meanging of HIV/AIDS in recovery from substance use: A qualitative study of HIV-Positive Wwomen in New York. Health Care for Women International, 26(4), 308-324. https://www.tandfonline.com/doi/abs/10.1080/07399330590925835.

World Health Organization. (2021, March 5). The Global Health Observatory: Explore a world of health data. Retrieved from https://www.who.int/data/gho. 